\title{
SPECIES COMPOSITION AND DIVERSITY OF CAST NET FISHERIES IN NEW CALABAR RIVER, NIGER DELTA, NIGERIA
}

\author{
Dienye, H. E., O. A. Olopade and S. A. Toby \\ Department of Fisheries, University of Portharcourt, Choba Rivers State, Nigeria
}

\begin{abstract}
A study on the catch composition and diversity of cast net fisheries was conducted between May and August, 2017 in the New Calabar River, Rivers state, using cast net of varying mesh sizes (1.5mm and $2.5 \mathrm{~mm})$. Fish samples were collected from three sampling stations, viz. Station1- Aluu, Station 2- Choba and Station 3Iwofe. The fish species recorded comprised of 26 species under 11 families, and one decapod crustacean. The three most abundant species were; Coptodon guineensis (25.11\%), Coptodon zilli (18.56\%) both from the Cichlidae family, and Penaeus nitialis (10.90\%) from the Penaeidae family, while the least abundant species was Liza grandisquamis $(0.13 \%)$ from the Mugilidae family. The diversity indices showed that station 2 recorded the highest number of species (21) while station 1 recorded the lowest with (12) species. Simpson's indexes of diversity, Simpson's reciprocal index, Shannon- weiner index, and Pielou's evenness index, were estimated. This study serves as a base line data which will assist relevant bodies in the management and conservation of fisheries resources in the New Calabar River. It is therefore recommended that for an improved and sustainable exploitation and management of fisheries resources of the New Calabar River, proper monitoring and management for fish stock must be done.
\end{abstract}

Keywords: Composition, diversity, Cast net, New Calabar River.

\section{INTRODUCTION}

All rivers in the Niger delta region of Nigeria support a rich and diverse assemblage of fish resources. Despite the vast resources, the riverine fisheries in the region are generally unorganized, fragmented and characterized with indiscriminate fishing practices which are decimating fish populations. Fishing not only reduces fish stocks, but excessive fishing pressure can also cause the collapse of fish populations and destabilization of the ecosystem (Gislason et al. 2000, Hutchings 2000) and many of the fishes become vulnerable, endangered, or critically endangered. Therefore, the study on impacts of fishing on species composition and quantitative change of fish aims to manage resources in an effective and reasonable way by predicting and evaluating the change and state of fish resources.

Fishery-dependent data collection is one of the most valuable tools available to fishery managers to determine the catch estimates for both target species and any by catch involved in the fishery, or of all species in a multi-species fishery. The catch estimates can be obtained in a variety of ways including the use of scientific observations, fishermen's logbooks (Hilborn and Walters 1992, Woll et al. 2006, King 2007) and questionnaire surveys (Berkes et al. 2000, Bergmann et al. 2004, McLeod and Leslie 2009). Fisheries observer programs are used worldwide to collect fisheries data including biological data, species composition, discards, etc.

For appropriate estimation of fish fauna, selection of fishing gear is important and directly influences species diversity and yield of the catch (Ju-Duk et al. 2015). The fish resources are exploited with numerous and ingenious gears. Scott (1968) described gill net, cast net, hand-line, fish fence and screens and traps of various kinds as the commonly used fishing gear in rivers in the Niger Delta. In Northern Nigeria fisheries, the cast net catches more fish than any other single type of fish gear (Reeds et al. 1967). The cast net is the one of the most widely used artisanal fishing in Nigerian brackish as well as coastal waters (FAO 1969). Cast net can cover a large area per deployment, compared with a throw trap, and is efficient where the gill net and the seine net are ineffective to use (Stein III et al. 2014). Detailed study on the catch rate, catch composition and catch size of cast net is scarce in the 
region. Therefore, the present study was carried out to determine the species composition and the potential of cast net fisheries in New Calabar River so that proper management advisory can be formulated to maintain the resilience of the species and sustainable harvest of the resource.

\section{MATERIAL AND METHODS}

The study area is the section of the New Calabar River as shown in Fig. 1. The New Calabar River lies between longitude $006^{\circ} 53^{\prime}-53^{\circ} 86^{\prime} \mathrm{E}$ and latitude $04^{\circ} 53^{\prime}-19^{\circ} 20^{\prime} \mathrm{N}$ in Choba, Rivers State, Nigeria. The entire river course is situated between longitude $7^{\circ} 60^{\prime} \mathrm{E}$ and latitude $5^{\circ} 45^{\prime} \mathrm{N}$ in the coastal area of the Niger Delta and empties into the Atlantic Ocean. The New Calabar River region has an annual rainfall between 2000 and $3000 \mathrm{~mm}$ (Abowei 2000). The New Calabar River contributes to fisheries resources in Rivers State and it is one of the River systems of the Niger Delta. Communities depend on the River for agricultural, industrial, domestic and recreational uses (Dienye 2015).Three sampling stations (S1-Aluu, S2-Choba and S3-Iwofe) were established along the main course of the river. Fish species were collected monthly for four consecutive months (May to August, 2017) from the three sampling stations with the assistance of local artisanal fishers using different cast nets $(9 \mathrm{~m}$ length, $9 \mathrm{~m}$ width and $1 / 2 \mathrm{~cm}$ mesh). The mesh sizes of the cast net was 15 and $25 \mathrm{~mm}$. Species were identified in the field and all the fishes length (total length), weight and girth (in front of the first dorsal fin) were measured. $0.1 \mathrm{~cm}$ (total length, TL), and weighed to the nearest $0.1 \mathrm{~g}$ (weight, $\mathrm{W}$ )

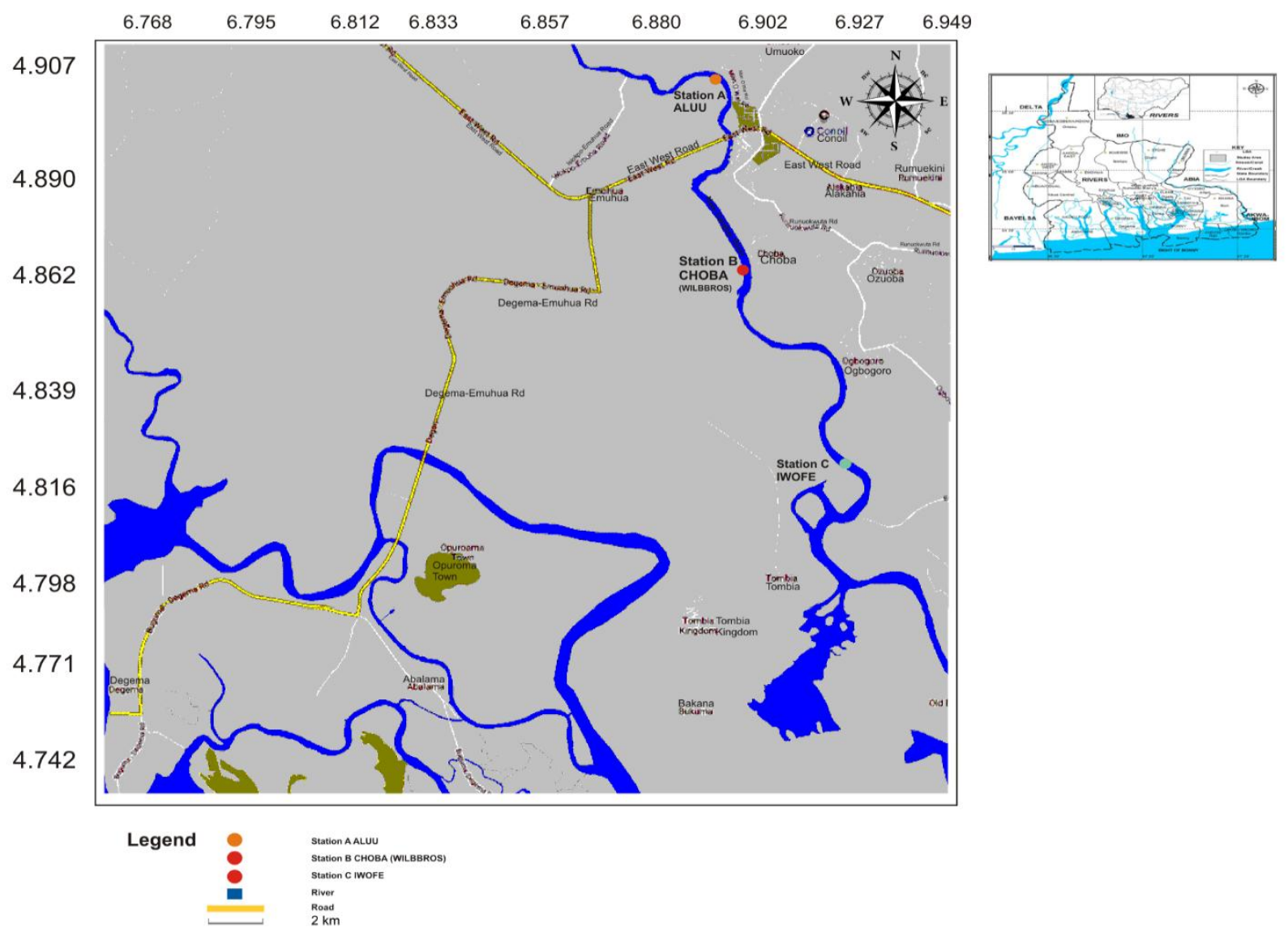

Fig. 1. Map showing the study area. 


\section{RESULTS AND DISCUSSION}

A total of 26 fish species belonging to 11 families was found in the river. One shell fish species Penaeus nitialis belonging to the family Penaeidae was also recorded during the study (Table 1). The dominant family in the New Calabar River was Cichlidae (55.9\%) and was represented by the species Coptodon guineensis, Coptodon zillii, Sarotherodon melanotheron, Sarotherodon galilaeus, Coptodon dageti, Pelmatolapia mariae, Pelvicachromis taeniatus, Chromidotilapia Guntheri and Hemichromis fasciatus. This was followed by the Mugilidae (11.8\%) with three species viz. Liza falcipinnis, Mugil cephalus and Liza grandisquamis. While the fish families Elopidae, Haemulidae, Monodactylidae and Sphyraenidae were represented by single species each viz. Elops lacerta, Pomadasys jubelini, Monodactylus sebae and Sphyraena barracuda, respectively. Penaeus nitialis was the only shell fish species recorded during the study. The species abundance and their biomass of the catch during the study were also shown in Table 1. Based on the individuals caught, the most dominant species was Coptodon guineensis comprising $25.11 \%$ of the total catch followed by Coptodon zillii (18.56\%) and Liza falcipinnis (10.19\%), whereas the dominant species in terms of biomass were Pelmatolapia mariae (9.10\%), Sphyraena barracuda (9.09\%) and Coptodon guineensis (7.11\%).

Table 1. Checklist of species and caught with cast net in the new Calabar river.

\begin{tabular}{|c|c|c|c|c|c|c|c|}
\hline \multirow{2}{*}{ Family } & \multirow{2}{*}{ Scientific name } & \multirow{2}{*}{ Common name } & \multirow{2}{*}{$\begin{array}{l}\text { Frequency with } \\
\text { percentage }(\%)\end{array}$} & \multirow{2}{*}{$\begin{array}{l}\text { Weight } \quad \text { with } \\
\text { percentage }(\%)\end{array}$} & \multicolumn{3}{|c|}{ Station } \\
\hline & & & & & 1 & 2 & 3 \\
\hline \multirow{9}{*}{ Cichlidae } & Coptodon guineensis & Guinean tilapia & $387(25.11 \%)$ & $121.80(7.11 \%)$ & + & + & + \\
\hline & Coptodon zillii & Red-belly tilapia & $286(18.56 \%)$ & $101.96(5.95 \%)$ & + & + & + \\
\hline & Coptodon dageti & & $47(3.05 \%)$ & $96.15(5.61 \%)$ & + & + & + \\
\hline & Sarotherodon melanotheron & Black-chin tilapia & $66(4.28 \%)$ & $86.06(5.02 \%)$ & + & & + \\
\hline & Sarotherodon galilaeus & Mango tilapia & $53(3.44 \%)$ & $59.96(3.50 \%)$ & + & + & + \\
\hline & Pelmatolapia mariae & Spotted tilapia & $6(0.39 \%)$ & $156.00(9.10 \%)$ & + & + & \\
\hline & Pelvicachromis taeniatus & Bone back Tilapia & $6(0.39 \%)$ & $57.33(3.34 \%)$ & & & + \\
\hline & Chromidotilapia guntheri & Guenther's mouth brooder & $4(0.26 \%)$ & $55.75(3.25 \%)$ & & + & \\
\hline & Hemichromis fasciatus & Banded jewel-fish & $4(0.26 \%)$ & $57.33(3.34 \%)$ & & + & \\
\hline \multirow[t]{3}{*}{ Mugilidae } & Liza falcipinnis & Sickle-fin mullet & $157(10.19 \%)$ & $97.39(5.68 \%)$ & + & & + \\
\hline & Liza grandisquamis & Large scaled mullet & $2(0.13 \%)$ & $13.50(0.78 \%)$ & & + & + \\
\hline & Mugil cephalus & Striped mullet & $24(1.56 \%)$ & $73.88(4.31 \%)$ & + & + & + \\
\hline \multirow[t]{2}{*}{ Clupeidae } & Sardinella maderensis & Madeiran sardinella & $31(2.01 \%)$ & $30.26(1.76 \%)$ & & + & + \\
\hline & Ethmalosa fimbriata & Bonga & $17(1.10 \%)$ & $57.06(3.33 \%)$ & & + & \\
\hline \multirow[t]{2}{*}{ Alestidae } & Brycinus nurse & Characin, Nurse tetra & $37(2.40 \%)$ & $65.57(3.82 \%)$ & + & + & + \\
\hline & Brycinus macrolepidotus & Large scales robber & $18(1.17 \%)$ & $51.78(3.02 \%)$ & & + & \\
\hline \multirow[t]{2}{*}{ Claroteidae } & Chrysicthys aluиensis & Unguli & $12(0.78 \%)$ & $39.50(2.30 \%)$ & + & & \\
\hline & Chrysicthys nigrodigitatus & Mud-fish & $10(0.65 \%)$ & $50.90(2.97 \%)$ & & + & + \\
\hline \multirow[t]{2}{*}{ Lutjanidae } & Lutjanus dentatus & African brown snapper & $32(2.08 \%)$ & $64.09(3.74 \%)$ & & + & + \\
\hline & Lutjanus agennes & African red snapper & $21(1.36 \%)$ & $65.14(3.80 \%)$ & & & + \\
\hline \multirow[t]{2}{*}{ Carangidae } & Caranx hippos & Black tailed trevally & $18(1.17 \%)$ & $25.72(1.50 \%)$ & + & + & + \\
\hline & Trachinotus teraia & Shortfin pompano & $10(0.65 \%)$ & $27.10(1.58 \%)$ & & + & \\
\hline Elopidea & Elops lacerta & West African Lady-fish & $74(4.80 \%)$ & $15.45(0.90 \%)$ & & + & + \\
\hline Haemulidae & Pomadasys jubelini & Sompat grunt & $23(1.49 \%)$ & $21.70(1.27 \%)$ & & + & + \\
\hline Monodactylidae & Monodactylus sebae & African moony & $22(1.43 \%)$ & $31.09(1.81 \%)$ & + & + & + \\
\hline Sphyraenidae & Sphyraena barracuda & Great barracuda & $6(0.39 \%)$ & $155.83(9.09 \%)$ & & + & + \\
\hline Penaeidae & Penaeus nitialis & Southern Pink Shrimp & $168(10.90 \%)$ & $34.22(1.99 \%)$ & & & + \\
\hline
\end{tabular}

The species zonation in Table 1 shows that four (4) species Coptodon guineensis, Coptodon zilli, Sarotherodon galilaeus and Coptodon dageti of the family Cichlidae were found across the three sampling stations while one (1) specie each was recorded from the families Mugilidae (Mugil cephalus), 
Alestidae (Brycinus nurse), Carangidae (Caranx hippos) and Monodactlylidae (Monodactylus sebae). The diversity indices of the species caught in the New Calabar River is shown in Table 3 which indicate that Choba (Station 2) recorded a total number of 21 species which was the highest, followed by Iwofe (Station 3) with 20 species recorded, and then Aluu (Station 1) with only 12 species recorded. The number of individuals caught at each stations was 821 (Iwofe), followed by 540 (Choba), and 180 (Aluu) (Table 4). The simpson's index for the three stations was 0.26 (Aluu), 0.14 (Choba) and 0.13 (Iwofe), while the Simpson's index of diversity was 0.74 (Aluu), 0.86 (Choba) and 0.87 (Iwofe). The Simpson's reciprocal index recorded was 3.90 (Aluu), 7.09 (Choba) and 7.54 (Iwofe). The Shannonwiener index recorded was 2.48 (Aluu), 3.04 (Choba) and 3.00 (Iwofe); and Pielou's evenness index (J') was 0.33 (Aluu), 0.76 (Choba) and 0.69 for Iwofe (Table 2).

Table 2. Diversity indices of cast net in the New Calabar River.

\begin{tabular}{lccc}
\hline Parameter & \multicolumn{3}{c}{ Station } \\
\cline { 2 - 4 } & 1 & 2 & 3 \\
\hline Number of species & 12 & 21 & 20 \\
Number of individuals & 180 & 540 & 821 \\
Simpsons index of diversity 1-D & $0.74^{*}$ & 0.86 & $0.87 * *$ \\
Simpson's reciprocal index & $3.90^{*}$ & 7.09 & $7.54^{* *}$ \\
Shannon-Weiner index & $0.33^{*}$ & $3.04 * *$ & 0.69 \\
Pielou's evenness index $\left(\mathrm{J}^{\mathrm{i}}\right)$ & $0.33^{*}$ & $0.76^{* *}$ & 0.69 \\
\hline
\end{tabular}

*Lowest calculated value ** Highest calculated value

Sample size and the minimum and maximum length measured for each species are presented in Table 3. Most of the samples consisted mainly of juveniles. The total length of fish specimens ranged from an average size of $8.79 \pm 0.25$ recorded for Caranx hippos to $20.96 \pm 0.41 \mathrm{~cm} \mathrm{Liza} \mathrm{falcipinnis.} \mathrm{The}$ cast net of mesh caught fishes of body girths range of $2.15 \pm 0.04 \mathrm{~mm}$ recorded for Elops lacerta to $7.94 \pm 0.22 \mathrm{~mm}$ recorded for Ethmalosa fimbriata. Fishes with body girths smaller than $2.15 \mathrm{~mm}$ which were not entangled would have escaped.

Table 4 shows the variations in number of individuals captured with different mesh sizes and catch rate with respect to three sites during the period of study. The fish catches decreased in number as the mesh size increased from $15 \mathrm{~mm}$ to $25 \mathrm{~mm}$. The cast net with mesh size $15 \mathrm{~mm}(813)$ recorded more individuals than mesh size $25 \mathrm{~mm}$ (728). The mesh size $15 \mathrm{~mm}$ captured almost all individuals, but the most susceptible species to mesh size $15 \mathrm{~mm}$ were Coptodon guineensis (184), Liza falcipinnis (123) and Coptodon zillii (115). In addition, the results showed that the least susceptible species to mesh size of $15 \mathrm{~mm}$ were Chromidotilapia guntheri, Chrysicthys nigrodigitatus, Ethmalosa fimbriata, Hemichromis fasciatus, Sarotherodon galilaeus, Sarotherodon melanotheron and Sphyraena barracuda. The most susceptible species to mesh size 25mm were Coptodon guineensis (203) and Coptodon zillii (171). Pomadasys jubelini, Chrysicthys aluuensis, Chrysicthys nigrodigitatus, Monodactylus sebae, Hemichromis fasciatus and Pelmatolapia mariae were the least caught species with the 25 mesh size. The selectivity of the mesh size $25 \mathrm{~mm}$ was low with four species conspicuously absent (unrepresented).

Station 3 had the highest catch rates with the 821 fishes followed by station 2 and station 1, respectively. In Station 3, the dominant was Coptodon guineensis followed by Penaeus nitialis and Coptodon zillii, respectively. While in stations 2 and 3 the dominant species were Coptodon guineensis and Coptodon zillii, respectively (Table 4).

In this study, a total of 11 families and 26 fish species was identified from cast net fisheries. The diversity of freshwater fishes stem largely from the fact that streams, rivers, lakes and wetlands are embedded in terrestrial landscapes which limit the dispersal of freshwater organisms by promoting 
habitat isolation (Berra 2007). This is in contrast with the findings of Ibim et al. (2016) who recorded a higher number in the New Calabar River. This could probably be due to duration of sampling and selectivity of gear used in the present study. The number of species could vary depending upon differences in the sampling methods and sampling effort, as well as fish abundance (Olopade and Rufai 2014). The area of operation of a gear, the inconsistant behavior of the fish relative to the gear, and the size of the fish determine the part of a stock that can be caught by a gear. Furthermore, species may develop avoidance behavior towards gear, which will result in lower catch ability.

Table 3. Size and girth selectivity of cast net in new Calabar river.

\begin{tabular}{|c|c|c|c|c|}
\hline \multirow[t]{2}{*}{ Species } & \multicolumn{2}{|c|}{ Total length $(\mathrm{cm})$} & \multicolumn{2}{|c|}{ Girths (cm) } \\
\hline & Mean+SE & Range & Mean+SE & Range \\
\hline Coptodon guineensis & $16.35 \pm 0.25$ & $8.7-33.7$ & $7.12 \pm 0.22$ & $1.9-59$ \\
\hline Coptodon zillii & $15.69 \pm 0.23$ & $9.3-30.1$ & $7.25 \pm 0.37$ & $2.8-79$ \\
\hline Coptodon dageti & $16.16 \pm 0.52$ & $9.5-26.3$ & $6.79 \pm 0.27$ & $4.1-10.1$ \\
\hline Sarotherodon melanotheron & $16.19 \pm 0.38$ & $8.3-23.5$ & $6.33 \pm 0.18$ & $2.7-10.4$ \\
\hline Sarotherodon galilaeus & $13.56 \pm 0.54$ & $7.8-22.8$ & $5.90 \pm 0.64$ & $3.1-37$ \\
\hline Pelmatolapia mariae & $18.25 \pm 1.67$ & $13.2-22$ & $7.60 \pm 1.01$ & $4.4-9.7$ \\
\hline Pelvicachromis taeniatus & $15.07 \pm 0.36$ & $14.1-16.5$ & $3.33 \pm 0.15$ & $2.9-3.8$ \\
\hline Chromidotilapia guntheri & $14.25 \pm 0.39$ & $13.2-15$ & $4.80 \pm 0.17$ & $4.3-5.1$ \\
\hline Hemichromis fasciatus & $14.33 \pm 0.45$ & $13-14.9$ & $6.70 \pm 0.64$ & $4.8-7.5$ \\
\hline Liza falcipinnis & $20.96 \pm 0.41$ & $9.1-37.1$ & $6.04 \pm 0.11$ & $2.7-10.7$ \\
\hline Liza grandisquamis & $9.80 \pm 0.70$ & $9.1-10.5$ & $3.00 \pm 0.20$ & $2.8-3.2$ \\
\hline Mugil cephalus & $19.27 \pm 0.68$ & $14.7-27.1$ & $5.67 \pm 0.16$ & $3.9-7.3$ \\
\hline Sardinella maderensis & $11.04 \pm 0.23$ & $9.2-13.5$ & $3.31 \pm 0.13$ & $2.1-4.6$ \\
\hline Ethmalosa fimbriata & $15.76 \pm 0.26$ & $13.6-17.3$ & $7.94 \pm 0.22$ & $5.3-8.6$ \\
\hline Brycinus nurse & $17.04 \pm 0.49$ & $12.9-23.3$ & $5.95 \pm 0.17$ & $4.5-7.3$ \\
\hline Brycinus macrolepidotus & $15.23 \pm 0.67$ & $9.6-22.5$ & $5.50 \pm 0.22$ & $4.3-7.2$ \\
\hline Chrysicthys aluuensis & $13.45 \pm 1.47$ & $9.9-22.4$ & $3.63 \pm 0.30$ & $2.9-5.4$ \\
\hline Chrysicthys nigrodigitatus & $15.11 \pm 1.62$ & $9.8-22.3$ & $4.67 \pm 0.64$ & $2.9-9.6$ \\
\hline Lutjanus dentatus & $16.24 \pm 0.42$ & $12.8-20.6$ & $6.52 \pm 0.26$ & $4.8-10.4$ \\
\hline Lutjanus agennes & $16.36 \pm 0.56$ & $11.7-20.8$ & $6.45 \pm 0.30$ & $5.2-10.5$ \\
\hline Caranx hippos & $8.79 \pm 0.25$ & $7.3-10.5$ & $6.13 \pm 2.05$ & $3.5-41$ \\
\hline Trachinotus teraia & $10.83 \pm 0.92$ & $7.5-14.1$ & $5.15 \pm 0.41$ & $3.6-6.5$ \\
\hline Elops lacerta & $12.76 \pm 0.30$ & $7.6-15.7$ & $2.15 \pm 0.04$ & $1.5-2.8$ \\
\hline Pomadasys jubelini & $10.89 \pm 0.30$ & $8.8-14.3$ & $4.67 \pm 0.07$ & $4.2-5.3$ \\
\hline Monodactylus sebae & $9.63 \pm 0.16$ & $8.8-10.7$ & $5.89 \pm 0.29$ & $3.7-7.3$ \\
\hline Sphyraena barracuda & $31.48 \pm 4.93$ & $19.3-45$ & $4.52 \pm 0.60$ & $2.9-6$ \\
\hline Penaeus nitialis & $15.16 \pm 0.25$ & $8.6-20.5$ & $2.94 \pm 0.06$ & $1.3-6.1$ \\
\hline
\end{tabular}

The dominant family in the New Calabar River was Cichlidae. This is in agreement with the findings of Olopade and Dienye (2018) who reported the abundance of cichlids in the New Calabar River. Their abundance have been associated to natural-history traits, such as high reproductive rates, high rates of juvenile and adults survival or the strong competitive abilities that allow them to dominate other species (Van Dyke 2003). The abundance (richness) is the number of species present in a community. The result of this study showed that Coptodon guineensis had the highest abundance (richness), followed by Coptodon zillii, while the species with the lowest abundance (richness) was Liza grandisquamis in the samples in the study area. This was attributed to good parental care of members of the family Cichlidae which gives a considerable advantage in the colonization of their chosen habitat.

Fishing efficiency is commonly expressed in terms of numbers or mass of fish captured by a fishing gear in a unit of time. Most of the samples consisted mainly of juveniles and the total length of fish specimens ranged from an average size of $8.79 \pm 0.25$ to $20.96 \pm 0.41 \mathrm{~cm}$. The fish catches decreased in 
number as the mesh size increased from $15 \mathrm{~mm}$ to $25 \mathrm{~mm}$ for example the cast net with mesh size $15 \mathrm{~mm}$ (813) recorded more individuals than mesh size $25 \mathrm{~mm}$ (728). Cast nets are selective for lower size ranges, and larger, faster-moving fish can escape the falling net, but may become entangled in the process (Welcomme 2001). Fish body length and girth are related to biological parameters, such as condition and swimming capability, and the different girth types determine the probability of different ways of capture by a fishing gear. The cast net of mesh caught fishes of body girths ranging from $2.15 \pm 0.04 \mathrm{~cm}$ to $7.94 \pm 0.22 \mathrm{~cm}$. The fishes, with head and body girths smaller than $2.15 \mathrm{~cm}$ were not entangled escaped. This is an indication of a declining fishery and stock depletion. In Nigerian water bodies, intensive fishing activity has impacted negatively on fish size as they are not allowed to grow to maximum size (Atobatele and Ugwumba 2011). This obviously poses a threat to the fish fauna in the New Calabar River. No implementation of conservation method was observed during the period of study indicates less or no attention by the appropriate authority, i.e. government organizations. Immediate management is essential.

Table 4. Cast net selectivity and catch rates in new Calabar River.

\begin{tabular}{|c|c|c|c|c|c|c|}
\hline \multirow[t]{2}{*}{ Species } & \multirow[t]{2}{*}{ Frequency } & \multicolumn{2}{|c|}{ Mesh Sizes (cm) } & \multicolumn{3}{|c|}{ Station } \\
\hline & & 1.5 & 2.5 & 1 & 2 & 3 \\
\hline Coptodon guineensis & 387 & 184 & 203 & 64 & 136 & 187 \\
\hline Coptodon zillii & 286 & 115 & 171 & 63 & 113 & 110 \\
\hline Coptodon dageti & 47 & 10 & 37 & 4 & 32 & 11 \\
\hline Sarotherodon melanotheron & 66 & 1 & 65 & 3 & 0 & 63 \\
\hline Sarotherodon galilaeus & 53 & 2 & 51 & 3 & 8 & 42 \\
\hline Pelmatolapia mariae & 6 & 5 & 1 & 3 & 3 & 0 \\
\hline Pelvicachromis taeniatus & 6 & 0 & 6 & 0 & 0 & 6 \\
\hline Chromidotilapia guntheri & 4 & 4 & 0 & 0 & 4 & 0 \\
\hline Hemichromis fasciatus & 4 & 3 & 1 & 0 & 4 & 0 \\
\hline Liza falcipinnis & 157 & 123 & 34 & 5 & 77 & 75 \\
\hline Liza grandisquamis & 2 & 2 & 0 & 0 & 0 & 2 \\
\hline Mugil cephalus & 24 & 19 & 5 & 3 & 5 & 16 \\
\hline Sardinella maderensis & 31 & 31 & 0 & 0 & 21 & 10 \\
\hline Ethmalosa fimbriata & 17 & 4 & 13 & 0 & 17 & 0 \\
\hline Brycinus nurse & 37 & 10 & 27 & 10 & 19 & 8 \\
\hline Brycinus macrolepidotus & 18 & 18 & 0 & 0 & 18 & 0 \\
\hline Chrysicthys aluuensis & 12 & 8 & 4 & 12 & 0 & 0 \\
\hline Chrysicthys nigrodigitatus & 10 & 4 & 6 & 0 & 1 & 9 \\
\hline Lutjanus dentatus & 32 & 28 & 4 & 0 & 20 & 12 \\
\hline Lutjanus agennes & 21 & 7 & 14 & 0 & 0 & 21 \\
\hline Caranx hippos & 18 & 12 & 6 & 7 & 5 & 6 \\
\hline Trachinotus teraia & 10 & 8 & 2 & 0 & 10 & 0 \\
\hline Elops lacerta & 74 & 65 & 9 & 0 & 35 & 39 \\
\hline Pomadasys jubelini & 23 & 18 & 5 & 0 & 1 & 22 \\
\hline Monodactylus sebae & 22 & 20 & 2 & 3 & 8 & 11 \\
\hline Sphyraena barracuda & 6 & 2 & 4 & 0 & 3 & 3 \\
\hline Penaeus nitialis & 168 & 110 & 58 & 0 & 0 & 168 \\
\hline Total & 1541 & 813 & 728 & 180 & 540 & 821 \\
\hline
\end{tabular}

According to Ali et al. (2015), ecological parameters of a group of species, such as species abundance, species dominance, species evenness and Shannon wiener index, are indicators of the health status of any habitat. The evenness is the distribution of species sampled among species in the community, and the biotic indices of Shannon-wiener information function, Pielou's evenness, Simpson's index were fairly distributed in the stations. Biligrami (1988) recommended better condition 
of water body for fish diversity when Shannon Weaver diversity index ranged from 3.0 to 4.5. That's mean the water body is light to slightly polluted. This may be due to domestic discharge, dredging activities, oil pollution and poor water quality from the adjacent lands. So, it is felt that the condition of the water body is not good and needs to make rules and regulations for better management of the water body. The biodiversity index seeks to characterize the diversity of a sample or community by a single number (Magurran 1988). According to King (1991) most commercially and scientifically important fish species occurring in the Niger Delta waters can be landed all year round by artisanal fishers, but there are months when they are more abundant. With the results obtained from this present study, the biodiversity of fish fauna in the New Calabar River, using cast net was high.

The total icthyofauna assemblage of the New Calabar River for the duration of this research work recorded 26 fish species from 11 families, and one decapod crustacean. It also showed the catch composition and selectivity of cast net, as well as, fish stock abundance in the New Calabar River. This study serves as a base line data which will assist relevant bodies in the management and conservation of fisheries resources in the New Calabar River.

Further studies should also be carried out on the fish assemblage of the New Calabar River, using different gears to monitor the fish stock and to get more information on their abundance, gear selectivity and biology, and also laws and order should be enforced by relevant agencies in the management and conservation of our water bodies.

\section{REFERENCES}

Abowei, J. F. N. 2000. Aspect of the Fisheries of the Lower Nun River, Niger Delta. Ph.D. Thesis. Department of Animal and Environmental Biology, University of Port Harcourt, Nigeria. 248 pp.

Ali A., S. Addo, Z. A. Lawan and A. Ebenezer. 2015. Feedng habit and condition factor for Oreochromis niloticus in Lake Alau, North Eastern Nigeria. Int. J. Fish. Aquat. Stud. 3(1): 406-409.

Atobatele, O. E. and O. A. Ugwumba. 2011. Condition factor and diet of Chrysichthys nigrodigitatus and Chrysichthys auratus (Siluriformes: Bagridae) from Aiba Reservoir, Iwo, Nigeria. Revista de Biología Tropical. 59(3): 1233-1244.

Bergmann M., H. Hinz, R. E. Blyth, M. J. Kaiser, S. I. Rogers and M. Armstrong. 2004. Using knowledge of fishers and fisheries scientists to identify possible ground fish essential fish habitats. Fish. Res. 66: 373-379.

Berkes, F., J. Colding and C. Folke. 2000. Rediscovery of traditional ecological knowledge as adaptive management. Ecological Applications. 10: 1251-1262.

Berra, T. M. 2007. Freshwater fish distribution. University of Chicago Press. 615 pp.

Biligrami, K. S. 1988. Biological monitoring of rivers, problems and prospect in India. Aquatic Ecotogvicology, Proceedings of Indo-Dutch Symposium Educations, pp. 245-250.

Dienye, H. E. 2015. Species Diversity of Macrophytes of the New Calbar River, Niger Delta, Nigeria. Int. J. Fish. Aquat. Stud. 3(1): 410-414.

FAO. 1969. Fisheries survey in Western and Midwestern Region of Nigeria. United Nations Development Programme (UNDP), Food and Agricultural Organization, SF: 74/NIR 6, Rome, Italy. 142 pp.

Gislason, H., M. Sinclair, K. Sainsbury and R. O’boyle. 2000. Symposium overview: incorporating ecosystem objectives within fisheries management. ICES J. Mar. Sci. 57: 468-475. 
Hilborn, R. and C. J. Walters. 1992. Quantitative fisheries stock assessment: choice, dynamics and uncertainty. Chapman and Hall, New York. 538 pp.

Hutchings, J. A. 2000. Collapse and recovery of marine fishes. Nature. 406: 882-885.

Ibim A. T., O. O. Gogo and F. Igbani. 2016. The Ichthyofaunal Assemblage of the Lower and Upper Reaches of New Calabar River, Rivers State, Niger Delta, Nigeria. J. Environ. Earth Sci. 6(9): 186197.

Ju-Duk, Y., K. Jeong-Hui, L. Hae-Jin and J. Min-Ho. 2015. Use of the cast net for monitoring fish status in reservoirs distributed in the Korean peninsula. J. Ecol. Environ. 38(3): 383-388.

King, R. P. 1991. The biology of tilapia mariae Bovlenger 1899 (Perciformes: Cicchlidae) in a Nigeria Rainforest stream. Ph.D. Thesis. Department of Zoology, University of Port Harcourt, Nigeria. 298 pp.

King, M. 2007. Fisheries biology, assessment and management. Fishing News Books, London. 400 pp.

Magurran, A. E. 1988. Ecological Diversity and its Measurement. Princeton University press, Princeton, New Jersy. 179 pp.

McLeod, K. L. and H. M. Leslie. 2009. Ecosystem-based management for the oceans. Island Press, Washington, DC. 392 pp.

Olopade, O. A. and H. E. Dienye. 2018. Distribution and abundance of cichlids in the New Calabar River, Nigeria. J. Fish. 6(2): 318.

Olopade, O. A. and O. P. Rufai. 2014. Composition, abundance and diversity of the Family Cichlidae in Oyan Dam, Ogun State, Nigeria. Bio Divers. J. 15(2): 195-199.

Reed, W., J. Burchard and A. J. Hopson. 1967. Fish and fisheries of Northern Nigeria. Ministry of Agriculture, Kaduna Government Printer, Northern Nigeria. 226 pp.

Scott, J. S. 1968. Morphometrics, distribution, growth and maturity of offshore sand launce (Ammodytes dubius) on the Nova Scotia banks. J. Fish. Res. Board Can. 25: 1775-1785.

Kainji Lake Fisheries Promotion Project Technical Report Series 12, ISBN 978-037-011-0, ISSN: 11191449.

Stein III, W., P.W. Smith and G. Smith. 2014. The cast net: an overlooked sampling gear. Mar Coast Fish. 6: 12-19.

VanDyke, F. 2003. Conservation Biology: Foundations, Concepts, Applications. McGraw-Hill Companies, New York. 441 pp.

Welcomme, R. L. 2001. Inland fisheries: ecology and management. Fishing News Books, Blackwell Science, Oxford, UK. 358 pp.

Woll A. K., G. I. van der Meeren and I. Fossen. 2006. Spatial variation in abundance and catch composition of Cancer pagurus in Norwegian waters: biological reasoning and implications for assessment. ICES Journal of Marine Science. 63: 421-433.

DOI: http://dx.doi.org/10.3329/jbcbm.v4i1.37873 